\title{
FROM CLIMATE CHANGE TO CUSTOMER DIALOGUE-CSR IN THE SERVICE SECTOR
}

\author{
Katri JAKOSUO \\ European Parliament, Belgium
}

\begin{abstract}
Strategically, corporate social responsibility (CSR) is important for the competitiveness of enterprises. CSR requires engagement with internal and external stakeholders and it can bring benefits such as cost savings, better customer relationships and human resource management, and more innovations. It can also create new markets and opportunities for growth. The main purpose of this study is to describe what the benefits of CSR are, along with the challenges and ways of cooperating in general, especially in the service sector. The qualitative research is based on two well-known Finnish organizations, Fazer and Kesko, annual reviews and corporate responsibility reports from 2011. According to the results, CSR is a part of day-to-day management and the CSR concept is very broad. It contains many different issues from climate change to customer dialogue. Companies are also ready to take courageous decisions, if these decisions support their own strategy. Results also show that not only the business size, but also the ownership structure seems to affect companies' CSR choices.
\end{abstract}

Keywords: CSR, economic performance, environmental performance, service sector, social performance

\section{INTRODUCTION}

At the general level corporate social responsibility (CSR) concerns actions by companies over and above their legal obligations towards society and the environment. The European Commission (2011) defines CSR as "a concept whereby companies integrate social and environmental concerns in their business operations and in their interaction with their stakeholders on a voluntary basis".

In companies, the view of the CSR discussion is often too theoretical and quite confusing, and is targeted at listed companies. For example, SMEs' CSR should make available to owner-managers of SME a very practical manual that they can use to bring about profitable, sustainable growth. (UEAPME 2011.)

Strategically CSR is important for the competitiveness of enterprises. CSR requires engagement with internal and external stakeholders in order to bring benefits such as cost savings, better customer relationships and human resource management, and more innovation. It can also create new markets and opportunities for growth.

The purpose of this study is to describe what the benefits of CSR are, and accepted practices, especially in the service sector.

\section{LITERATURE REVIEW}

In general CSR promotes ideas about good corporate citizenship in profitable economic and ethical, environmental and social codes. Quite often CSR is a synonym for corporate citizenship, sustainable responsibility, social responsibility or social performance.

\section{History of CSR}

CSR has a long history. For decades, CSR discussions have generally focused on the role of business in society and the nature of a firm's social responsibility. In the 1950s the primary focus of CSR was on a business's reputation in fulfilling its responsibilities towards society, including charitable deeds. In the 1960s the main opinion was that CSR is not the answer to all the social problems of a business, but rather, it does contain important ethical issues for guidance purposes. In the early 1970s reactions by enterprises to social and environmental issues became a focus of attention. At this time many researchers and managers emphasised the social role of enterprises, thinking that enterprises lose their 
place in society, if they don't exploit their social power. On the other hand, there were also critics such as Friedman, who in 1970 wrote that the only social responsibility of business firms is to maximise profits. (Galbreath 2009, 109-111; Castelló \& Lozano 2009; Moura-Leite \& Padgett 2011, 529-532.)

In the 1980s the technical and operational environment evolved further and business and social interests drew closer. For example, enterprises became more responsive to their internal and external stakeholders. During the 1990s the idea of CSR came to be accepted generally as, little by little, knowledge of CRS extended. Finally in the 2000s CSR became an important part of strategic and operational management. For example, in 2004 the International Organization for Standardization (ISO) published ISO 14000 which gives the requirements for environmental management systems and in 2010 ISO 26000, which is a guide to corporate social responsibility. (Galbreath 2009, 112-113; ISO 2010; Moura-Leite \& Padgett 2011, 532-535.)

Over the course of time researchers and communities have chosen different ways of classifying CSR (Table 1). For example, Carroll's $(1979 ; 2000)$ pyramid-like view of social responsibility was based on the idea that companies have four good corporate citizens' responsibilities. For example, the company must be profitable, yet it must comply with the law and respect peoples' moral rights.

\section{Table 1. Three Different Ways of Classifying CSR (Carroll 1979; 2000; Elkington 1997; ISO 2010)}

\begin{tabular}{|c|c|c|}
\hline Carroll's pyramid & Elkington's triple bottom line & ISO 26000 \\
\hline Economic responsibilities & Profit: Economic performance & Organizational governance \\
\hline Legal responsibilities & People: Social performance & Human rights \\
\hline Ethical responsibilities & Planet: Environmental performance & Labour practices \\
\hline \multirow[t]{4}{*}{ Philanthropic responsibilities } & & The environment \\
\hline & & Fair operating practices \\
\hline & & Consumer issues \\
\hline & & $\begin{array}{l}\text { Community involvement and } \\
\text { development }\end{array}$ \\
\hline
\end{tabular}

There are also some differences between the models. Elkington's (1997) famous triple bottom line concept also takes into account environmental issues and for the social performance aspects mentioned by Carroll $(1979 ; 2000)$, Elkington's concept one is much larger. Even ISO 26000 stresses economic, social and environmental performance, and social issues get the most visible role in the model (ISO 2010). The ISO 26000 is also business oriented, because it integrates CSR in practice. This model explains clearly what CSR means, what issues organizations need to address in their CSR strategy and what the best practices are for implementing CSR effectively and efficiently (Earth Charter International 2011).

\section{CSR's Political and Cultural Challenges}

When we talk about companies' CSR, we cannot ignore the political and cultural context. One problem is that because CSR is linked in the value systems and culture tenets, it may mean different things in different places to different people and at different times. Therefore, it is important to understand the structure and context of CSR in different countries.

There has been considerable debate concerning the issue of whether such "responsibilities" should be voluntary or not, especially regarding the enforcement of labour standards and basic human rights. For example, in countries with a strong community culture such as India, Mexico and Africa, CSR is a part of everyday life. (Hodges 2007; Gupta 2011; Hinson \& Ndhlovu 2011.) In Europe community culture differs and therefore policy and legislation play a significant role in CSR and welfare ideology.

Midttun, Gautesen, and Gjølberg (2006) and Moreno (2010) have found four different types of European welfare regimes:

- The Social-Democratic Nordic with a welfare state ideology of growth and full employment, minimisation of family dependence and free tax-funded services. 
- The Liberal Anglo-Saxon which emphasises deregulation of the labour market, wage flexibility and retrenchment in social expenditure, is focused on poverty alleviation, is financed by taxes, and incorporates residual means-tested services and flat-rate benefits.

- The Corporatist Continental which is based mainly on interaction between employers and trade unions and financed by the contributions they make. A sharp distinction is made between labour market "insiders" and "outsiders".

- The Familialistic Mediterranean which emphasises the central role played by the family, strong household micro-solidarity and other solidarity networks and welfare based on citizenship programmes, occupational benefits and services.

For example, in Finland CSR has traditionally been largely implicit in nature, meaning that the state is assumed to take care of social issues and there has not been as strong a philanthropic tradition as in many countries. Moreover, Finnish CSR is based mainly on holistic legislation and the state's primary role is to provide basic services, such as minimal social security, public health and free education with free school meals.

CSR's cultural challenges become more concrete when we move from political ideology to the operational level. Gupta (2011) has clarified the differences between the views on corporate social responsibility of U.S. and Indian consumers. According to his results, there are differences between the USA and India; for example, ethical business practices, public safety and consumer welfare. These countries also differed in how they make profits for shareholders and how they help the underprivileged.

\section{CSR as Part of Strategy}

According Galbreath (2009, 114), CSR has to integrate into a company's business strategy and determine strategy in terms of what the company's goals and targets at different levels and business areas are. Without this connection it is difficult to succeed. CSR offers a systematic way of taking into account how different responsibilities can be built into part of the business strategy. Therefore, it is important that CSR strategy also has the same approach as business strategy, and it must contain, for example, a mission, strategic issues, customer needs and resources. The Body Shop is a good example of a successful company. It has addressed ethical consumerism and opposed the use of animals for experiments in their strategic and operational business management. This approach has duly led to world-wide success.

In the operational management view, CSR policy invites some major challenges. One of these challenges is associated with responsibilities and roles: Who is responsible to whom for what, precisely? The other challenges relate to the attitude that CSR is too costly, difficult and timeconsuming. It is true that implementation of CSR demands investment, for example, for training, documentation or waste disposal, but usually these costs are only short-term investments. There might also be some challenges which are related to employees and other stakeholders. For example, employees in different levels of organisations may understand CSR in different ways, and this is also true of external stakeholders such as trade unions and shareholders. From the supply chain view the main barriers to CSR could be a lack of resources for supplier audits, difficulty in ensuring that all suppliers fulfil the code of conduct, differences in culture and management style, low levels of social standards and high levels of corruption, in some countries. (Cegarra-Navarro \& Martínez-Martínez 2009; Fenwick 2010.) Perrini, Russo and Tencati (2007) found that business size also affects CSR choices: Larger firms tend to develop specific, formal CSR strategies that focus on particular stakeholder needs.

\section{CSR Benefits}

CSR provides companies with different benefits like increased quality of products and services, customer loyalty, trust, global business opportunities, positive brand attitude and combats negative publicity. CSR may also have a positive outcome on the company's financial performance. (Balabanis, Phillips \& Lyall 1998; Cegarra-Navarro \& Martínez-Martínez 2009.) According to Iturrioz, Aragón, Narbaiza and Ibañez (2004, 425-426) and Bhattacharyya (2010, 84), CSR activities can help companies, for example, create new business (product-market) opportunities, streamline logistical activities in terms of cost and environmental parameters and develop administrative systems 
and procedures which uphold socially responsible and environmentally friendly management practices.

CSR can also help companies build strategic alliances, renovate the business and discover new business opportunities (Iturrioz, Aragón, Narbaiza and Ibañez 2004, 426-427). For example, German's Osram is a good example of how responsible thinking can generate innovation and new business models. Osram recognised that approximately 1.6 billion people in the world are dependent on lamps that burn fossil fuels, typically kerosene. These lamps are not only extremely inefficient, not ecofriendly and uneconomic, but they also pose a risk to health for those using them. This finding inspired Osram to develop an entirely new business model which is based on a transportable light with a rechargeable battery and a battery loading station with a solar roof for recharging the batteries offgrid. (Loew, Clausen, Hall, Loft \& Braun 2009, 22-25.)

In the service sector, for example, the Dutch Rabobank helps its customers and partners to make responsible investments and move towards clean and sustainable business operations providing sustainable loans, and funding for clean and sustainable technology. Among other things Rabobank implements its CSR policy by participating in international discussions on ethics and sustainability issues, such as the Roundtable on Sustainable Palm Oil and the Roundtable on Human Rights. (Strandberg 2005, 20-23; Rabobank 2012.)

\section{CSR and Consumers}

According to researchers, there is a significant relationship between CSR and consumer responses. These researchers define that socially responsible consumers seek to minimise or eliminate any harmful effects and maximise the long-term beneficial impact on society. Therefore, a socially responsible consumer actively looks for products from those companies which aid society, and avoids buying products from companies which harm society. (Mohr, Webb, \& Harris 2001; Mohr, \& Webb 2005.)

Gao (2009, 280-281) emphasises that consumers' opinions about the CSR activities of companies are not only based on the nature of CSR activities: These opinions are also based on the contrast effect between companies' CSR ability, its past and its negative social impact of operation compared with the activities of other companies. Even those consumers who believe in an altruistic motivation for a company's CSR activity will not respond positively or even negatively to the company if there is a significant negative gap between the company's CSR effort and consumers' expectations.

Several studies have concluded that companies' efforts in multiple CSR domains (e.g. corporate giving and community involvement) had a direct effect on the attractiveness of the companies' products and a positive effect on how customers estimate the companies. Researchers have also found direct links between CSR and customer satisfaction and between CSR and a company's market value. However, researchers have also found that CSR did not always lead to customer satisfaction. Especially, in those companies, whose capacity to innovate is low, CSR actually reduced customer satisfaction levels and harmed market value. (Mohr, Webb \& Harris 2001; Sen \& Bhattacharya 2001; Luo \& Bhattacharya 2006.)

Researchers have also shown that transparency and communication play important roles in CSR. Transparency is linked to honesty and is regarded as a significant factor in building customer trust. (Chung, Luo \& Wagner 2006; Forsman-Hugg, Paananen, Isoniemi, Pesonen, Mäkelä, Jakosuo \& Kurppa 2006.) Also, if companies pay more attention to communication between different actors, such as customers, it will be easier to identify those quality problems and responsibility issues which could have serious effects on the smooth functioning of the supply chain.

\section{Data and Methods}

The analyses and the findings are based on two famous Finnish service sector organizations' annual reviews and corporate responsibility reports (Fazer 2011; Kesko 2011). The study has been limited to observing only those goals and actions which are related to CSR.

The Fazer Group is a family owned company which has two business areas, Fazer Food Services and Fazer Bakeries \& Confectionery. The Fazer Group's turnover was 1,513.6 million euros in 2010 and company was a market leader in Finland, where in that year Fazer was the most popular brand. The number of employees was 16,573, of which 5,384 were employed in the Nordic 
Countries, 3,966 in Russia and 1,579 in the Baltic Countries. Fazer and its scientific research partners have introduced innovations; for example, Fazer Rye Fibre ${ }^{\circledR}$ the total fibre content of which is $49 \%$, compared to $16 \%$ for whole kernel rye. (Fazer 2011.)

Kesko is a listed company which provides trading sector services. Kesko manages retail chains and provides services for the chains purchasing logistics, network development and IT management. Kesko's chain operations comprise of about 2,000 stores in eight countries (Finland, Belarus, Estonia, Latvia, Lithuania, Norway, Russia and Sweden). In 2010, the Kesko Group's net sales totalled 8,777 million euros. At the end of 2010, Kesko had agreements with 1,270 K-retailer entrepreneurs as well as some 170 other retailer entrepreneurs. In 2010 Kesko was ranked 33rd on 'The Global 100 Most Sustainable Corporations in the World' list. Kesko was selected for the Dow Jones sustainability indexes DJSI World and DJSI Europe. (Kesko 2011.)

In this study the data are used to describe, rather than to explain, the phenomenon. The data are also a source of practical examples for other companies. The qualitative analysis of textual data is based on Elkington's (1997) widely used triple bottom line concept (Table 1).

\section{RESULTS}

\section{CSR and Strategic Management}

Both Fazer and Kesko stress that CSR policies are an integral part of management and day-to-day activities. According to Kesko's CSR strategy, its CSR is a voluntary but measurable commitment, based on the Group's values, principles, objectives and strategy. Operations in the areas of economic, social and environmental responsibility are developed in accordance with the expectations of the key stakeholder groups. Kesko's CSR strategy is tied to its HR strategy: It mentions that some of its objectives are to be the most attractive workplace, to have the most competent and motivated personnel and to achieve the best labour productivity in the trading sector.

Laws and regulations are an important part of strategic management. Both companies mention that they observe national and international laws and regulations, global ISO standards, the principles of the UN Global Compact as well as national and EU policy, such as the Finnish Personal Data Act, the Finnish Government's energy policy and the EU's Integrated Energy and Climate Policy.

As a listed company, Kesko's decision-making and administration also comply with the Finnish Limited Liability Companies Act, the rules and guidelines of NASDAQ OMX Helsinki Ltd, and the Finnish Corporate Governance Code, for example. Kesko also mentions that the K-Group's environmental management is based on the ICC Business Charter for Sustainable Development.

Both companies report that they cooperate with the various stakeholders and companies play an active role in various organizations in Finland and at the European level. For example, Fazer is a founding member of the HEALTHGRAIN Forum, which aims to provide information on the health benefits of wholegrain cereals. It is notable that neither Fazer nor Kesko engage in direct lobbying with politicians and the authorities.

CSR politics is not always based on successes. For example, Fazer reports that it had problems with the progress of the environmental certification (ISO14001) of Finnish bakeries in 2010. Kesko reports that the sector's level of reputation was perceived to be quite good, although responsibility was considered to be at a slightly lower level compared to reputation. Overall this probably reflects the fact that stakeholders do not have a clear perception of corporate responsibility and companies' efforts to develop it.

\section{Economic Performance}

Economic or financial performance is an important part of CSR, because without a profitable economy, business is not possible. As a listed company Kesko shows clearly that one of its key strategic objectives is profitable growth in Finland and especially in the fast developing Russian markets.

Compared with Kesko, Fazer handles only a very few economic issues in its CSR report. Despite this both CSR reports contain several aspects of CSR, such as proactive risk management, spending on locally-based suppliers or management salaries, bonuses and pensions (Table 2). 
Journal of Global Strategic Management | V. 6 | N. 1 | 2012-June | isma.info | 69-79 | DOI: 10.20460/JGSM.2012615787

Table 2. Examples of the Economic Performance Mentioned in the CSR Reports

\begin{tabular}{|c|c|c|}
\hline Target & Aspects of CSR & Practical Examples \\
\hline \multirow{6}{*}{$\begin{array}{l}\text { Long-term } \\
\text { focus and } \\
\text { profitable } \\
\text { grow guided } \\
\text { by ethics } \\
\text { principles }\end{array}$} & Spending on locally-based suppliers & \multirow{2}{*}{$\begin{array}{l}\text { Kesko encourages K-food retailers to } \\
\text { complement their selections with local } \\
\text { purchases. }\end{array}$} \\
\hline & Local hiring & \\
\hline & Proactive risk management & \multirow{2}{*}{$\begin{array}{l}\text { Fazer pays closer attention to brand, because } \\
\text { most of its growth comes from international } \\
\text { markets and new product concepts. }\end{array}$} \\
\hline & Management bonuses and pensions & \\
\hline & Good corporate governance & \multirow{2}{*}{$\begin{array}{l}\text { Kesko Corporation distributes at least } 50 \% \text { of } \\
\text { its earnings per share excluding non-recurring } \\
\text { items such as dividends. }\end{array}$} \\
\hline & Profitability of operations & \\
\hline
\end{tabular}

Kesko reports openly that about 90 of its managers have a performance-based bonus scheme, and that there are also two option schemes (2003 and 2007). Kesko also emphasises that salaries, taxes and social security contributions paid by Kesko have an impact on regional economic well-being (e.g. jobs) and the accessibility of products and services.

\section{Environmental Performance}

Environmental issues are the oldest part of Finnish CSR reports. One reason was that these issues are also more easily measurable than, for example, the well-being of an employee. In 2010 the CSR reports of Fazer and Kesko contained several aspects of CSR, such as water and energy consumption (Table 3).

\section{Table 3. Examples of the Environmental Performance Mentioned in the CSR Reports}

\begin{tabular}{|l|l|l|}
\hline Target & Aspects of CSR & Practical Examples \\
\hline $\begin{array}{l}\text { Reduce negative } \\
\text { impacts on the } \\
\text { environment, like } \\
\text { eutrophication } \\
\text { and climate } \\
\text { change, and } \\
\text { support } \\
\text { sustainable } \\
\text { development and } \\
\text { biodiversity }\end{array}$ & Water consumption, recycled and reused & $\begin{array}{l}\text { Nearly all K-food stores also use condensation } \\
\text { heat from cooling units. }\end{array}$ \\
\cline { 2 - 2 } & Environmental impacts of land use & \\
\cline { 2 - 2 } & Direct/indirect greenhouse gas emissions & $\begin{array}{l}\text { Fazer Food Services in Finland introduced low- } \\
\text { carbon lunch alternatives, in which special } \\
\text { attention was paid to keeping the carbon footprint } \\
\text { of the ingredients as low as possible. }\end{array}$ \\
\cline { 2 - 2 } & Promotion of sustainable agriculture & Electricity purchased by Kesko is carbon-free and \\
\cline { 2 - 3 } & Direct and indirect energy consumption & renewable energy sources. \\
\cline { 2 - 3 } & Materials used & \\
\cline { 2 - 3 } & Environmental advice to customers & \\
\hline
\end{tabular}

Both companies also mentioned that they use environmental certification ISO14001, and environmental issues are a part of personnel training. Fazer reports that it tries to minimise the amount of food waste by developing the sourcing process, restaurant menus and the material processes of restaurants, for example.

\section{Social Performance}

Several CSR models emphasise social responsibility. For example, when economic or environmental issues constitute just one section of CSR strategy, social performance and ethics are included in many 
sections. In this study the CSR strategy of both companies include both external and internal social CSR aspects important for different stakeholders, such as employees, customers and communities (Table 4).

\section{Table 4. Examples of the Social Performance Mentioned in the CSR Reports}

\begin{tabular}{|c|c|c|}
\hline Target & Aspects of CSR & Practical Examples \\
\hline \multirow{3}{*}{$\begin{array}{l}\text { Employee: Attractive } \\
\text { workplace with } \\
\text { competent } \\
\text { and motivated } \\
\text { personnel }\end{array}$} & $\begin{array}{l}\text { Training and development } \\
\text { programmes }\end{array}$ & \multirow{3}{*}{$\begin{array}{l}\text { Fazer cooperates with vocational institutions and } \\
\text { offers trainee positions for those leaving primary } \\
\text { school. }\end{array}$} \\
\hline & $\begin{array}{l}\text { Statutory and voluntary occupational health } \\
\text { and safety }\end{array}$ & \\
\hline & $\begin{array}{l}\text { Good working conditions and human rights } \\
\text { throughout the supply chain }\end{array}$ & \\
\hline \multirow{4}{*}{$\begin{array}{l}\text { Customers: Customer } \\
\text { satisfaction and } \\
\text { customer well-being }\end{array}$} & Safety and quality of products and services & \multirow{4}{*}{$\begin{array}{l}\text { Kesko's customers can visit the www.pirkka.fi } \\
\text { website to trace their UTZ certified Pirkka coffee } \\
\text { down to the coffee farm. } \\
\text { For consumers' wishes Fazer Food Services' } \\
\text { decision to start using only stock preparations } \\
\text { which contain no monosodium glutamate (E621). }\end{array}$} \\
\hline & The traceability of products & \\
\hline & Promotion of healthy lifestyles & \\
\hline & Customer dialogue & \\
\hline \multirow{3}{*}{$\begin{array}{l}\text { Stakeholder and } \\
\text { Investor Relations: } \\
\text { Corporate governance }\end{array}$} & Responsible marketing and sales & \multirow{3}{*}{$\begin{array}{l}\text { Kesko provided more information on responsibility } \\
\text { in stores, marketing, on pirkka.fi and in its own } \\
\text { magazine Pirkka. }\end{array}$} \\
\hline & Responsibility communications & \\
\hline & Well-known and valued brand & \\
\hline \multirow{3}{*}{$\begin{array}{l}\text { Community: } \\
\text { Supporting well-being } \\
\text { of local community }\end{array}$} & Research and other partnerships & \multirow{3}{*}{$\begin{array}{l}\text { In Sweden Fazer supports the Friends association, } \\
\text { which aims to prevent bullying at schools. }\end{array}$} \\
\hline & Support to non-profit operations & \\
\hline & Visits, lectures and presentations & \\
\hline
\end{tabular}

One example of external issues is the companies' work and productivity programmes. For example, Fazer Food Services have developed their working methods at Finnish and Swedish restaurants. The target of this programme was to clarify the importance of each employee's contribution to the restaurant's result. Fazer and Kesko also have statutory equality plans which were drawn up to promote equal pay for comparable duties. Kesko also emphasises that one of its CSR aims is to promote healthy lifestyles for its customers. For this reason, all Kesko's private label products with high salt, sugar or fat content were reformulated by the end of 2010. This reformulation supports the targets of the EU white paper- "A Strategy for Europe on Nutrition, Overweight and Obesity related Health Issues".

Further, Fazer and Kesko have operations abroad and this is reflected in their CSR politics. For example, Kesko reports that expansion and operations in Russia and Belarus involve country risks. The unpredictability of officials and sudden changes in legislation and the interpretation and application of laws, as well as corruption can complicate operating activities or delay expansion. Fazer mentions that its business units in Russia boosted the implementation by publishing detailed guidelines that supplement the ethic principles.

\section{CSR and Consumers}

Consumer interest in corporate responsibility is continuing to increase, despite the fact that purchasing decisions are strongly based on price. Fazer's and Kesko's examples show that one function of service sector companies is to offer products that promote sustainable development and to help customers make good choices. For this reason, Kesko offers a guide to sustainable living which is available from 
the company's hardware stores, the object being to help customers reduce the impact on climate change of living. It also offers recycling points for household batteries, bottles and cans in shops and markets.

Fazer and Kesko have also noticed that product quality, safety and traceability are important issues for today's consumers. For this reason these companies are interested in maintaining constant dialogue with their consumer and they want to encourage consumers to give them feedback.

Service sector companies often emphasise that standards, openness, traceability of products and selfmonitoring are an important part of product safety. Kesko stated that one example of its product safety policy is a list of chemicals which are completely banned or only permitted to a limited extent, for example, in home textiles, shoes and clothes. This list is based on the requirements of Finnish and EU chemicals legislation (REACH) as well as Kesko's own policy. Additionally, Kesko requires the supplier to observe international auditing standards, for example, BCR, IFS, GlobalGAP or ISO 22000 , and the company is constantly looking for more BSCI audited or SA8000 certified suppliers.

\section{DISCUSSION AND LIMITATIONS}

The purpose of this study is to describe what the benefits of CSR are, its challenges and accepted practices, especially in the service sector. My qualitative examination is based on two famous Finnish service sector organizations' annual reviews and corporate responsibility reports. The study is limited to observing only those goals and actions which are related to CSR. These reports were published in 2010.

The literature review showed that CSR has a long history which started in the 1950s, and at the European level CSR is strongly linked to social policy. For example, in the Nordic welfare states public institutions have traditionally played a significant role both in providing a societal safety net and levelling inequalities, but in America and Eastern Europe the role of public institutions is much smaller in social policy. (Midttun, Gautesen, \& Gjølberg 2006; Castelló \& Lozano 2009; Galbreath 2009; Moreno 2010; Moura-Leite \& Padgett 2011; Gupta 2011.) From the companies' perspective CSR can create both economic benefit and consumer utility and it can also make enterprises more attractive than competitors. It can also bring a new competitive status in the future along with benefits to shareholders and society at large. (Balabanis, Phillips, \& Lyall 1998; Cegarra-Navarro \& MartínezMartínez 2009; Bhattacharyya 2010.)

Fazer and Kesko are good examples of Finnish CSR. Both companies are well-known and wellrespected national brands, and globally Kesko is recognised as one of the world's most sustainable corporations. Fazer and Kesko have realised that CSR strategy cannot be separated from practice and must linked to business strategy and day-to-day activities. It appears that not only the size of the business, but also the ownership structure seems to affect its CSR choices: According to my study the listed company Kesko presented a more in-depth report of CSR issues in its corporate responsibility report than the family-owned Fazer in its annual review.

The main result of the qualitative analysis is that according to my findings CSR is a very broad concept. It contains many different issues from climate change to customer dialogue. Economic performance, like profitability growth and risk management, is usually one of the main pillars of CSR. When I compared Fazer and Kesko, I noticed that Fazer concerns itself with only a very few economic issues in its CSR report. One reason might be that Fazer is a family-owned company, unlike Kesko, which is a listed company with strict reporting requirements.

These companies have also had the courage to make bold CSR decisions. For example, despite the fact that some Finnish consumers are opposed to nuclear power, Kesko's electricity has been produced by means of nuclear power and renewable energy sources. Kesko has explained that it wants to reduce negative impacts on the environment, like climate change and for this reason it wishes to use carbon-free electricity.

As far as social performance is concerned it was interesting to observe that in the service sector CSR strategy takes into account the perspectives of the enterprise's main stakeholders, employees and customers. Developing better products and services, and providing experiences which exceed customer expectations are also methods of increasing customer satisfaction. From a political and cultural view it is worth noting that many companies usually reported on how they train their personnel or take care of their personnel's health or work safety, since in the Nordic countries, which 
have been greatly influenced by social democracy, these matters are part of a company's statutory duties.

These findings have some practical implications for representatives of companies and policy makers. The main practical contribution of the study is to demonstrate that even though economic, social and environmental performance are equally important, without economic performance companies can afford to implement neither social nor environmental performance. Companies also need a uniform CSR strategy even if they have subsidiaries and partners in other countries with different cultures. This study also provides important information concerning those members of the European Parliament and other stakeholders who renew their common EU strategy on CSR, and who represent different national welfare policy backgrounds (Midttun, Gautesen \& Gjølberg 2006; Moreno 2010; European Commission 2011), because the results of this study highlight the importance of economic performance: Without profitable business it impossible to develop social or environmental responsibility.

The principal limitations of this study concern two aspects: The scope of the study and the simplicity of the data. First, the study was carried out mainly in the context of private service sector companies. Therefore, this means that the opinion of the public sector actors is less significant. Second, because the data consisted of only two companies, these data represent only a very small part of the service sector companies' view and a generalisation of the results is quite impossible. 


\section{REFERENCES}

Balabanis, G., Phillips, H. C. \& Lyall, J. (1998), Corporate social responsibility and economic performance in the top British companies, European Business Review, 98 (1), pp. 25-44.

Bhattacharyya, S. S. (2010), Exploring the concept of strategic corporate social responsibility for an integrated perspective, European Business Review, 22 (1), pp. 82-101.

Carroll, A. B. (1979), A Three-dimensional model of corporate performance, Academy of Management Review, 4 (4), pp. 497-505.

Carroll, A. B. (2000), Ethical challenges for business in the new millennium: Corporate social responsibility and models of management morality, Business Ethics Quarterly, 10 (1), pp. 33-42.

Castelló, I. \& Lozano, J. (2009), From risk management to citizenship corporate social responsibility: Analysis of strategic drivers of change, Corporate Governance, 9 (4), pp. 373-385.

Cegarra-Navarro, J.-G. \& Martínez-Martínez, A. (2009), Linking corporate social responsibility with admiration through organizational outcomes, Social Responsibility Journal, 5 (4), pp. 499-511.

Chung, Q.B., Luo, W. \& Wagner, W. P. (2006), Strategic alliance of small firms in knowledge industries-A management consulting perspective, Business Process Management Journal, 12 (2), pp. 206-233.

Earth Charter International (2011), ISO 26000 guidance for social responsibility and the earth charter, http://www.earthcharterinaction.org/invent/details.php?id=890.

Elkington, J. (1997), Cannibals with forks: The triple bottom line of 21st century business, Capstone, Oxford, England.

European Commission (2011), Communication from the Commission to the European Parliament, the Council, the European Economical and Social Committee and the Committee of the Regions: A renewed EU strategy 2011-14 for corporate social responsibility, European Union.

Fazer (2011), Fazer Group's annual review 2010.

Fenwick, T. (2010), Learning to practice social responsibility in small business: Challenges and conflicts, Journal of Global Responsibility, 1 (1), pp. 149-169.

Forsman-Hugg, S., Paananen, J., Isoniemi, M., Pesonen, I., Mäkelä, J., Jakosuo, K. \& Kurppa, S. (2006), Perspectives on quality and responsibility in the food chain, MTT Agrifood Research Finland. [in Finnish]

Galbreath, J. (2009), Building corporate social responsibility into strategy, European Business Review, 21 (2), pp. 109-127.

Gao, Y. (2009), Corporate social responsibility and consumers' response: The missing linkage, Baltic Journal of Management, 4 (3), pp. 269-287.

Gupta, S. (2011), Consumer stakeholder view of corporate social responsibility: A comparative analysis from USA and India, Social Responsibility Journal, 7 (3), pp. 363-380.

Hinson, R. E. \& Ndhlovu, T.P. (2011), Conceptualising corporate social responsibility (CSR) and corporate social investment (CSI): The South African context, Social Responsibility Journal, 7 (3), pp. 332-346.

Hodges, C. (2007), The potential for corporate social responsibility in Mexico: Some reflections, Social Responsibility Journal, 3 (1), pp. 34-39.

ISO (2010), ISO 26000, Guidance on social responsibility, International Organization for Standardization.

Iturrioz, C., Aragón, C., Narbaiza, L. \& Ibañez, A. (2009), Social responsibility in SMEs: A source of business value, Social Responsibility Journal, 5 (3), pp. 423-434.

Kesko (2011), Kesko Group's corporate responsibility report 2010.

Loew, T., Clausen, J., Hall, M., Loft, L. \& Braun, S. (2009), Case studies on CSR and innovation: Company cases from Germany and the USA, Institute 4 Sustainability. 
Luo, X. \& Bhattacharya, C.B. (2006), Corporate social responsibility, customer satisfaction, and market value, Journal of Marketing, 70 (October), pp. 1-18.

Midttun, A., Gautesen, K. \& Gjølberg, M. (2006), The political economy of CSR in Western Europe, Corporate Governance, 6 (4), pp. 369-385.

Mohr, L. A. \& Webb, D. J. (2005), The effects of corporate social responsibility and price on consumer responses, Journal of Consumer Affairs, 39 (1), pp. 121-147.

Mohr, L. A., Webb, D. J., \& Harris, K. E. (2001), Do consumers expect companies to be socially responsible? The impact of corporate social responsibility on buying behavior, Journal of Consumer Affairs, 35 (1), pp. 45-72.

Moreno, L. (2010), Welfare mix, CSR and social citizenship, International Journal of Sociology and Social Policy, 30 (11/12), pp. 683-696.

Moura-Leite, R. C. \& Padgett, R. C. (2011), Historical background of corporate social responsibility, Social Responsibility Journal, 7 (4), pp. 528-539.

Perrini, F., Russo, A. \& Tencati, A. (2007), CSR Strategies of SMEs and large firms: Evidence from Italy, Journal of Business Ethics 74 (3), pp. 285-300.

Rabobank (2012), Sustainability policy, http://www.rabobank.com/content/csr.

Sen, S. \& Bhattacharya, C.B. (2001), Does doing good always lead to doing better? Consumer reactions to corporate social responsibility, Journal of Marketing Research, 38 (2), pp. 225-243.

Strandberg, C. (2005), Best practices in sustainable finance, Strandberg Consulting.

UEAPME. (2011), Position on the green paper "The EU corporate governance framework", European Association of Craft, Small and Medium-Sized Enterprises. 